Case Study

\title{
Socio-economic Status of Farmers of Sitapur District of Uttar Pradesh: A Case
}

\author{
Mukesh Sehgal $^{1 *}$, Rajat Kumar ${ }^{2}$, Ram Kumar ${ }^{2}$, Daya S. Srivastava ${ }^{3}$, \\ Anand Kumar $\operatorname{Singh}^{3}$ and Saurbah ${ }^{3}$ \\ ${ }^{1}$ ICAR-National Research Centre for Integrated Pest Management (NCIPM), ICAR, Pusa \\ Campus, New Delhi-110012, India \\ ${ }^{2}$ Department of Plant Protection of Chaudhary CharanSingh University (CCSU), Meetut \\ (UP)250001, India \\ ${ }^{3}$ ICAR-Krishi Vigyan Kendra, Sitapur (Uttar Pradesh), India
}

*Corresponding author

\section{A B S T R A C T}

\section{Keywords \\ Socio-economic Status, Farmers, Literacy \\ Article Info \\ Accepted: \\ 15 June 2018 \\ Available Online: \\ 10 July 2018}

\section{Introduction}

Sitapur is one of the administrative districts of Uttar Pradesh which is located in the Eastern part adjacent to Uttar Pradesh India. Sitapur is located at $27.57^{\circ} \mathrm{N} 80.68^{\circ} \mathrm{E}$. It is located in the Gangetic Plain, with elevations ranging from $150 \mathrm{~m}$ above sea level in the north-west to 100 $\mathrm{m}$ in the south-east. The gradual rise in temperature starts in the months of February and becomes more rapid by March and April unless checked by more humid easterlies. The local hot and dusty winds, locally known as 'loo'; result in hot and scorching weather. The major crops grown in the district are tomato, sugarcane, and rice. The district has total population of $4,483,992$. The Literacy rate of the district is $63 \% \mathrm{http}: / / \mathrm{www}$.indiamapia. com/Sitapur.html.

The farmers are socio-economically backward as compared to the other district of Uttar Pradesh. Agriculture is the primary source of livelihood for the overwhelming majority of 
the population in the district. Majority of the farmers are engaged in agricultural and livestock rearing activities. The present study reveals the socio economic status of the farmers of the district with the following objectives.

To appraise the socio-economic condition of farmers in Sitapur District Of Utter Pradesh

To study the existing cropping and resource use patterns to locate the specific socioeconomic weaknesses in their production organization.

To find the social constraints that inhibit the adoption of new technology

\section{Materials and Methods}

The study was conducted with a sample of 400 farmers of thirty different villages of Sitapur district of Uttar Pradesh. A multistage purposive cum random sampling design was followed for selection of the respondents. The investigation was carried out with various problems faced by the farmers in Maholi and Hargao blocks of the district.

The data were collected by personal interview method using both structural schedule and semi-structured interview during 2016-17 by supplying the questionnaire mentioning the following salient points.

1. Average Population of the villages

2. Family Structure

3. Educational Status of Family Members

4. Housing Conditions

5. Electricity Facility

6. Source of Water

7. Mode of Transportation

8. Occupational

9. Land Holdings

10. Source of Irrigation

11. Farm Mechanization

12. Livestock
13. Difficulties

in Agriculture Improvement

14. Priorities for Future Investment

15. Source of Agricultural Information

16. Sources of Credit Supply

17. Cropping Pattern

18. Plant Protection

19. Dynamics of Crop Production

20. Marketing System of Agricultural Produce

21. Marketed Surplus of Farm Produce

22. Returns from Agricultural Produces

23. Literacy rate $(\%)$

24. Cropping Pattern

25. Soil type

26. Av. Pesticide used (/ha)

27. Knowledge about IPM

After completion of survey, a total of 800 filled in questionnaire were received and were analyzed to find out the socio economic condition of the farmers of the blocks.

\section{Results and Discussion}

In the present study, it was observed that the farmer are socio-economically backward as compared to the other district farmer of the studied area.

Agriculture is the primary source of livelihood for the overwhelming majority of the population. So as to eradicate the problems of villagers people, it is necessary for the policy makers to identify and quantify the socioeconomic factors which are inhibiting their growth and development.

The farmer owing to their life style and community habits and habitats have not been able to keep pace with the modern society. Farmer are not as advanced as the people of rest of India. The base line information gathered as part of study is included in the Table 1Table. 
Table.1 Base line information at Maholi and Hargao block of Sitapur District of Uttar Pradesh

\begin{tabular}{|c|c|c|c|}
\hline \multirow{2}{*}{$\begin{array}{l}\text { Sl. } \\
\text { No. }\end{array}$} & \multirow[t]{2}{*}{ Component } & \multicolumn{2}{|c|}{ Results } \\
\hline & & Maholi Block & Hargao Block \\
\hline 1 & Average Population of the village & & \\
\hline 2 & Average Family Structure & $\begin{array}{l}\text { Nuclear } \\
\text { Joint }\end{array}$ & $\begin{array}{l}\text { Nuclear } \\
\text { Joint }\end{array}$ \\
\hline 3 & $\begin{array}{l}\text { Average Educational Status of } \\
\text { Family Members }\end{array}$ & $\begin{array}{l}\text { Illiterate } \\
\text { High School } \\
\text { Graduate }\end{array}$ & $\begin{array}{l}\text { Illiterate } \\
\text { High School } \\
\text { Graduate }\end{array}$ \\
\hline 4 & Average Housing Conditions & $\begin{array}{l}\text { Kachcha } \\
\text { Pucca }\end{array}$ & $\begin{array}{l}\text { Kachcha } \\
\text { Pucca }\end{array}$ \\
\hline 5 & Electricity Facility & $\begin{array}{l}\text { Electrified } \\
\text { Unelectrified }\end{array}$ & $\begin{array}{l}\text { Electrified } \\
\text { Unelectrified }\end{array}$ \\
\hline 6 & Source of Water & $\begin{array}{l}\text { Tube Well } \\
\text { Hand pump } \\
\text { Pond } \\
\text { River }\end{array}$ & $\begin{array}{l}\text { Tube Well } \\
\text { Hand pump } \\
\text { Pond } \\
\text { River }\end{array}$ \\
\hline 7 & Mode of Transportation & $\begin{array}{l}\text { Two wheeler and } \\
\text { Public transport }\end{array}$ & Two wheeler \\
\hline 8 & Major Land Holdings & $\begin{array}{l}\text { Landless } \\
\text { Marginal } \\
\text { Small }\end{array}$ & $\begin{array}{l}\text { Landless } \\
\text { Marginal } \\
\text { Small }\end{array}$ \\
\hline 9 & Source of Irrigation & $\begin{array}{l}\text { Tube well } \\
\text { Pond } \\
\text { Other }\end{array}$ & $\begin{array}{l}\text { Tube well } \\
\text { Pond } \\
\text { Other }\end{array}$ \\
\hline 10 & Farm Mechanization & $\begin{array}{l}\text { Tractor } \\
\text { Pump set } \\
\text { Sprayer } \\
\text { Others }\end{array}$ & $\begin{array}{l}\text { Tractor } \\
\text { Pump set } \\
\text { Sprayer } \\
\text { Others }\end{array}$ \\
\hline 11 & Livestock & $\begin{array}{l}\text { Cow, Goat, Poultry and } \\
\text { Duck }\end{array}$ & Cow, Goat, Poultry and Pig \\
\hline 12 & $\begin{array}{l}\text { Difficulties in Agriculture } \\
\text { Improvement }\end{array}$ & $\begin{array}{l}\text { Irrigation } \\
\text { Credit } \\
\text { Transport } \\
\text { Agriculture Knowledge } \\
\text { Labour }\end{array}$ & $\begin{array}{l}\text { Irrigation } \\
\text { Credit } \\
\text { Transport } \\
\text { Agriculture Knowledge } \\
\text { Labour }\end{array}$ \\
\hline 13 & $\begin{array}{l}\begin{array}{l}\text { Source of } \\
\text { Information }\end{array} \\
\end{array}$ & $\begin{array}{l}\text { Extension staff, Mass Media and } \\
\text { Relatives }\end{array}$ & $\begin{array}{l}\text { Mass Media and } \\
\text { Relatives }\end{array}$ \\
\hline 14 & Sources of Credit Supply & Cooperative society & Nil \\
\hline 15 & Cropping Pattern & Rice, Sugarcane & Rice and Sugarcane \\
\hline 16 & Plant Protection & Use chemical & - \\
\hline 17 & $\begin{array}{l}\text { Marketing System of Agricultural } \\
\text { Produce }\end{array}$ & $\begin{array}{l}\text { Local traders } \\
\text { Village market }\end{array}$ & $\begin{array}{l}\text { Local traders } \\
\text { Middle man } \\
\text { Village market }\end{array}$ \\
\hline 18 & Soil type & sandy loamy & Sandy loam alkaline \\
\hline 19 & Average Pesticide used (/ha) & Very rarely & Very rarely \\
\hline 20 & Knowledge about IPM & & \\
\hline
\end{tabular}




\section{Suggestions}

Policy suggestions based on the findings from field study of farmers are presented for consideration:

Educational facilities should be provided for the people.

Positive steps should be taken to check the exploitation of the farmer.

Good, reliable transport and communication facilities should be provided.

Multiple cropping and intercropping should be actively encouraged. The government must make major moves to create permanent assets with farmers and provide infrastructural support for meeting input, credit and marketing needs.

Extension agencies must visit the villages and interact with farmers

Training should be provided to the farmer in different income generating activities.
Suitable steps should be taken by the Government so as to educate the farmers about the importance of crop loan and crop insurance facility.

The role of middle man should be minimized for more benefit to the farmers.

Hence concluded that if all the suggestions mentioned above are implemented in the villages, the development of those backward areas can be seen in near future. By introducing facilities of modern technology, their socioeconomic standard can be increased. Thus this weaker part of the society can be turned into the huge mass of human resource. However, further studies are required to know more about them.

\section{References}

http://www.indiamapia.com/Sitapur.html

\section{How to cite this article:}

Mukesh Sehgal, Rajat Kumar, Ram Kumar, Daya S. Srivastava, Anand Kumar Singh and Saurbah. 2018. Socio-economic Status of Farmers of Sitapur District of Uttar Pradesh: A Case. Int.J.Curr.Microbiol.App.Sci. 7(07): 1977-1980. doi: https://doi.org/10.20546/ijcmas.2018.707.232 